\title{
REVIEW : RISIKO STUNTING PADA ANAK YANG TINGGAL DI AREA PERTAMBANGAN EMAS SKALA KECIL
}

\author{
Stunting Risk of Child Live in Small-Scale Gold Mining Areas \\ ${ }^{1}$ Devi Puspita, ${ }^{2}$ Defi Patmasari, ${ }^{3}$ Sella, ${ }^{4}$ Dwi Purbayanti \\ ${ }^{1}$ Program Studi Analis Kesehatan, Universitas Muhammadiyah Palangkaraya, Palangka Raya, Indonesia \\ ${ }^{2}$ Program Studi Analis Kesehatan, Universitas Muhammadiyah Palangkaraya, Palangka Raya, Indonesia \\ ${ }^{3}$ Program Studi Analis Kesehatan, Universitas Muhammadiyah Palangkaraya, Palangka Raya, Indonesia \\ ${ }^{4}$ Program Studi Analis Kesehatan, Universitas Muhammadiyah Palangkaraya, Palangka Raya, Indonesia \\ *e-mail : puspitadevi689@gmail.com
}

\begin{abstract}
ABSTRAK
Pertambangan Emas Skala Kecil menggunakan merkuri untuk mengesktraksi emas. Paparan merkuri terhadap anak-anak dikaitakan dengan risiko berbagai gangguan kesehatan yang dapat menyebabkan stunting. Review ini disusun dengan tujuan untuk mengetahui dampak dari paparan merkuri terhadap anak yang tinggal di area Pertambangan Emas Skala Kecil. Metode yang digunakan dalam penyusunan narrative review ini adalah penelusuran informasi melalui internet dengan menggunakan google. Hasil penelusuran dari berbagai penelitian dan buku elektronik menyebutkan bahwa anak-anak yang tinggal di area PESK sangat rentan terhadap paparan merkuri baik secara inhalasi dengan menghirup uap merkuri atau ingesti dengan mengkonsumsi makanan atau minuman yang mengandung merkuri. Selain itu mereka juga sangat berisiko terhadap gangguan kesehatan seperti malnutrisi dan penyakit-penyakit infeksi yang merupakan faktor risiko dari terjadinya stunting. Berbagai faktor risiko yang mengancam Kesehatan anak-anak yg tinggal di area PESK yang dapat mengakibatkan stunting, namun masih sedikit penelitian yang mengaitkan antara paparan merkuri dengan stunting.
\end{abstract}

Kata kunci : Tambang Emas Tradisional, Merkuri, Stunting, Malnutrisi

\section{ABSTRACT}

Small Scale Gold Mining uses mercury to extract gold. Mercury exposure to children is associated with the risk of various health problems that can lead to stunting. This review was prepared with the aim of knowing the impact of mercury exposure on children living in the Small Scale Gold Mining area. The method used in the preparation of this narrative review is searching for information via the internet using google. Tracing results from various studies and electronic books stated that children living in ASGM areas are very vulnerable to mercury exposure either by inhalation by inhaling mercury vapor or ingestion by consuming food or drinks containing mercury. In addition, they are also very at risk of health problems such as malnutrition and infectious diseases, which are risk factors for stunting. Various risk factors that threaten the health of children living in ASGM areas that can lead to stunting, however, there is still little research linking mercury exposure to stunting.

Keyword : Traditional Gold Mining, Mercury, Stunting, Malnutrition

\section{PENDAHULUAN}

Tambang Emas Tradisional atau Pertambangan Emas Skala Kecil (PESK) menyebabkan polusi merkuri yang paling utama dibandingkan aktivitas manusia lainnya. Logam merkuri digunakan untuk mengekstraksi emas dari bijih sebagai amalgam yang stabil. Amalgam kemudian dipanaskan untuk menguapkan merkuri dan mengisolasi emasnya (Esdaile and Chalker, 2018). Uap merkuri yang 
dihirup oleh penambang dapat mengakibatkan gangguan fungsi kognitif, kerusakan saraf, tremor, gangguan pernafasan, kerusakan ginjal, dan beberapa masalah kesehatan lainnya (Park and Zheng, 2012). Untuk anak-anak dan janin, paparan polusi merkuri sangat berbahaya karena meningkatkan kemungkinan cacat fisik, kerusakan saraf, dan IQ yang lebih rendah. Risiko paparan merkuri ini juga diperparah dengan tingginya kadar merkuri yang terakumulasi dalam ikan, air dan makanan lainnya yang dikonsumsi oleh masyarakat di sekitar tambang (Esdaile and Chalker, 2018).

Rute paparan utama merkuri anorganik pada masyarakat yang tinggal di area tambang emas di Amazon adalah menghirup langsung uap merkuri saat amalgamsi dan paparan utama metil merkuri $(\mathrm{MeHg})$ adalah melalui konsumsi ikan, karena ikan merupakan makan pokok budaya lokal dan memancing merupakan kegiatan ekonomi yang utama di daerah tersebut (Wyatt et al., 2017; Feingold et al., 2020).

Peningkatan kandungan merkuri di rambut dikaitkan dengan penurunan kadar hemoglobin pada anak usia <12 tahun di Amazon (Weinhouse et al., 2017). Paparan merkuri terhadap anak-anak usia 3 bulan -8 tahun yang tinggal di area penambangan emas di Peru menunjukkan hasil mengalami status gizi yang buruk dengan $78 \%$ anak-anak mengalami anemia. Paparan merkuri dikaitkan dengan peningkatan risiko kekurangan nutrisi, seperti anemia karena gangguan fungsi hemoglobin, dimana merkuri bersaing dengan besi untuk berikatan dengan hemoglobin (Wyatt et al., 2017).

Menurut Vilcins et al. (2018) paparan merkuri merupakan faktor risiko yang berhubungan dengan terjadinya stunting. Marques et al. (2012) menyatakan bahwa anak-anak yang tinggal di sekitar tambang timah di Bom Futuro, Brazil menunjukkan hasil korelasi positif meskipun tidak signifikan antara kandungan metil merkuri yang ada di rambut dengan kejadian stunting.

Stunting merupakan istilah untuk pertumbuhan linier yang terganggu di tahun awal kehidupan (1000 hari pertama), yang mengakibatkan kegagalan untuk mencapai tinggi badan pada masa dewasa. Stunting dapat diukur dengan menggunakan $\mathrm{z}$-score tinggi badan menurut umur $(\mathrm{TB} / \mathrm{U})$ kurang dari -2 standar deviasi (SD) berdasarkan standar pertumbuhan menurut WHO (Laksono and Kusrini, 2019). Prediksi global menunjukkan bahwa satu dari lima anak akan mengalami stunting pada tahun 2020 (De Onis et al., 2012). Hasil Riskesdas 2007, 2013 dan 2018, di Indonesia angka stunting pada balita berada di atas $30 \%$ atau ada 3 balita stunting dari 10 balita yang dilahirkan di Indonesia (Laksono and Kusrini, 2019).

Stunting merupakan manifestasi dari malnutrisi kronis (Reinhardt and Fanzo, 2014). Stunting di masa kanak-kanak dapat mengakibatkan efek kesehatan yang negatif seperti penurunan perkembangan kognitif, dan pada saat dewasa dapat meningkatkan risiko komplikasi yang mengancam jiwa selama persalinan, penurunan kinerja, peningkatan faktor risiko penyakit kronis tidak menular seperti predisposisi obesitas, tekanan darah tinggi, dan penyakit kardiovaskuler (Vilcins et al., 2018).

Banyak penelitian tentang stunting difokuskan pada asupan makanan, namun masih sedikit bukti yang menunjukkan peran penting lingkungan pada kesehatan anak. Interaksi antara faktor lingkungan dan status gizi dapat mengakibatkan perubahan status kesehatan. Kami berhipotesis bahwa merkuri yang merupakan agen cemaran lingkungan dapat mempengaruhi serapan zat gizi dan berdampak negatif pada pertumbuhan anak. Kami mencari artikel sebelumnya yang mengulas tentang risiko stunting pada anak-anak yang tinggal di area tambang emas.

\section{METODE PENELITIAN}

Metode yang digunakan adalah studi literatur, yakni pendekatan yang dilakukan melalui studi kepustakaan dengan mencari informasi yang sesuai. Penelusuran informasi dilakukan melalui internet, dengan menggunakan Google. Referensi yang diperoleh berupa e-jurnal atau e-book baik dalam Bahasa Indonesia maupun Bahasa Inggris, terbitan tahun 2000-2020. Strategi pencarian jurnal dilakukan melalui Google Scholar, PubMed, dan Proquest dengan kata kunci stunting, anak-anak, tambang emas skala kecil, merkuri, malnutrisi, Z-score.

\section{PEMBAHASAN}

\section{Tambang Emas Tradisional dan Merkuri}


Tambang emas tradisional menggunakan merkuri adalah untuk memisahkan emas dari material lain setelah dilakukan pendulangan atau pencucian, dengan cara membentuk amalgam antara merkuri dan emas. Proses amalgamsi ini akan menghasilkan limbah berupa tailling yang mengandung merkuri, dan biasanya tailing ini akan dibuang ke air sungai atau tanah (Esdaile and Chalker, 2018).

Pembuangan tailing yang mengandung merkuri ke dalam tanah dan air merupakan bahaya serius bagi kesehatan manusia karena dapat membahayakan keamanan pangan dan mencemari air minum (Esdaile and Chalker, 2018). Air yang tercemar merkuri yang digunakan untuk irigasi juga menyebabkan tercemarnya tanaman pangan, seperti beras. Selain itu, merkuri dapat terbioakumulasi di dalam tubuh ikan, sehingga masyarakat yang tinggal di sekitar wilayah PESK yang biasa mengkonsumsi ikan sebagai sumber protein, dapat juga terpapar (Riaz et al., 2018).

Amalgam yang mengandung emas dan merkuri kemudian dipanaskan di atas api atau kompor untuk menguapkan merkuri dan mendapatkan emasnya. Uap merkuri ini sangat berbahaya bagi paru-paru, ginjal, hati, sistem kekebalan tubuh dan sistem saraf (Park and Zheng, 2012). Anak-anak diketahui relatif lebih rentan untuk terpapar merkuri karena anak-anak sering ikut terlibat dalam proses pembakaran amalgam (Schipper et al., 2015). Ohlander et al. (2013) menemukan bahwa anak-anak yang tinggal di daerah tambang emas tradisional di Chili berisiko terkena paparan $\mathrm{Hg}$ kronis akibat proses pembakaran amalgam dilakukan di dalam rumah. Selain itu, uap merkuri juga dapat menyebar jauh terbawa udara, yang dapat membahayakan orang lain yang tinggal disekitarnya (Schipper et al., 2015). Hasil penelitian Ohlander et al. (2013) menunjukkan risiko yang secara statistik signifikan terhadap peningkatan kadar $\mathrm{Hg}$ dalam sampel kuku pada anak-anak yang sering bermain di lingkungan di mana kegiatan pembakaran amalgam emas dilakukan.

\section{Dampak Kesehatan Anak-anak akibat Paparan Merkuri}

Paparan merkuri yang berasal dari tambang emas tradisional merupakan bahaya kesehatan yang serius, terutama bagi anak-anak yang tinggal, bermain dan bekerja di PESK. Di Indonesia dan Zimbabwe, 166 anak ditemukan memiliki kadar merkuri yang tinggi dalam darah, urin, dan rambut dibandingkan dengan kelompok kontrol, serta menunjukkan gejala khas keracunan merkuri, seperti ataksia (Bose-O'Reilly et al., 2008).

Anak-anak yang tinggal di daerah tambang emas tradisional dapat terdampak merkuri dalam bentuk (1) uap merkuri $\left(\mathrm{Hg}^{0}\right)$, (2) ion merkuri anorganik $\left(\mathrm{Hg}^{2+}\right)$ yang terbentuk dari uap $\mathrm{Hg}$ di lingkungan melalui oksidasi, dan (3) metil merkuri $\left(\mathrm{MeHg}^{+}\right)$, dibentuk di lingkungan tropis basah oleh bakteri. Uap merkuri dan metil merkuri bersifat sangat beracun, terutama bagi otak, karena kedua senyawa tersebut mudah diserap (uap $\mathrm{Hg}$ di paruparu, $\mathrm{MeHg}^{+}$di saluran pencernaan) dan keduanya merupakan senyawa lipofilik, yang dengan mudah melintasi sawar darah otak. Otak bayi yang sedang berkembang memiliki risiko yang tinggi terhadap paparan merkuri ini (Bose-O'Reilly et al., 2008).

Efek berbahaya akibat menghirup $\mathrm{Hg}$ antara lain masalah pencernaan, paru-paru, ginjal, sistem kekebalan tubuh dan sistem saraf (WHO, 2007). Anak-anak dan janin lebih rentan terpapar $\mathrm{MeHg}$ yang dapat menyebabkan masalah perkembangan saraf seperti keterbelakangan mental, perkembangan yang lambat, kehilangan penglihatan dan pendengaran, gangguan bahasa, tremor dan kehilangan ingatan. Selain itu telah dilaporkan suatu kondisi ekstremitas merah dan nyeri pada anak-anak telah dilaporkan terkena paparan $\mathrm{Hg}$ kronis yang disebut Acrodynia (Gibb and O'Leary, 2014).

Risiko paparan merkuri ini juga diperparah dengan tingginya kadar merkuri yang terakumulasi dalam ikan dan persediaan makanan lainnya di sekitar PESK (Esdaile and Chalker, 2018). Dilaporkan Indeks risiko kesehatan pada anak-anak yang berada disekitar PESK lebih tinggi dibandingkan orang dewasa dengan rerata jumlah $\mathrm{Hg}$ yang lebih tinggi pada anak-anak dibandingkan orang dewasa (Riaz et al., 2018).

Dampak dari pencemaran merkuri terhadap perairan dan ikan yang ada di area pertambangan menurut berpengaruh terhadap status gizi pada anakanak Herman (2009). Paparan merkuri dilaporkan dapat meningkatkan risiko kekurangan nutrisi, seperti anemia karena gangguan fungsi hemoglobin dari 
merkuri bersaing dengan besi untuk tempat pengikatan (Weinhouse et al., 2017).

Selain itu, masyarakat yang tinggal di PESK juga berisiko terhadap berbagai penyakit seperti malnutrisi atau gizi buruk, diare, malaria, tuberkulosis, parasit, dan penyakit lainnya. Gejala keracunan merkuri kadang-kadang tidak nampak secara langsung dan kadang diabaikan akibat stres menghadapi penyakit akut, kecelakaan kerja dan kemiskinan (Veiga et al., 2006).

\section{Risiko Stunting pada Anak yang Tinggal di Area Tambang Emas Tradisional}

Berbeda dengan pertambangan industri atau skala besar, penambangan emas skala kecil merupakan aktivitas yang dilakukan oleh penambang perorangan atau perusahaan kecil dengan menggunakan peralatan mekanis sederhana, modal terbatas, dan produktivitas rendah (WHO, 2016). Komunitas para penambang di PESK cenderung berasal dari keluarga miskin dan berpendidikan rendah, serta kebutuhan sehari-hari diperoleh bergantung pada mata pencaharian. Komunitas para penambang di PESK dihadapkan oleh berbagai masalah kesehatan masyarakat, termasuk malnutrisi atau gizi buruk terutama pada anak-anak (Zhang et al., 2020).

Status gizi yang buruk ditambah dengan paparan merkuri dapat mengakibatkan dampak buruk bagi kesehatan anak-anak yang tinggal di area PESK (Wyatt et al., 2019). Satu penelitian yang menemukan bahwa penduduk di yang tinggal di PESK lebih banyak mengkonsumsi makanan kemasan atau instant, lebih banyak gula dan lemak, dan lebih sedikit buah dan sayuran dibandingkan dengan penduduk yang tinggal di daerah pertanian. Kebiasaan tersebut juga dapat menjadi potensi malnutrisi pada anak-anak (Zhang et al., 2020).

Kondisi malnutrisi pada anak-anak sangat erat kaitannya dengan stunting (de Onis and Branca, 2016). Stunting atau perawakan pendek (shortness) berhubungan dengan kurangnya zat gizi dimasa lalu sehingga dikategorikan sebagai masalah gizi yang sifatnya kronis. Stunting dapat diketahui dengan melihat tinggi atau panjang badan, umur, dan jenis kelamin dari anak tersebut. Namun masih banyak orangtua yang tidak menyadari pentingnya melakukan pengukuran tinggi anak, sehingga persoalan stunting menjadi sulit diketahui. Hal ini lah yang menjadikan sunting sebagai fokus Sustainable Development Goals (SDGs) pada tahun 2025 pada target perbaikan gizi di dunia untuk menurangi angka stunting hingga 40\% (Kemenkes RI, 2018).

Stunting dapat diketahui dengan cara mengukur tinggi badan (TB) seorang anak yang dibandingkan dengan umur (U), selanjutnya dilakukan perhitungan skor Z-indeks TB/U. Seseorang dikatakan stunting bila Z-indeks TB/U di bawah -2 SD (Laksono and Kusrini, 2019). Kejadian stunting merupakan dampak dari kurangnya asupan gizi kronik baik dari segi kualitas maupun kuantitas akibat kondisi sosial ekonomi, gizi saat kehamilan, gizi saat bayi dan kesakitan (Kemenkes RI, 2018). Stunting pada anak menyebabkan terhambatnya perkembangan anak, dampak negatif akan berlangsung dimasa yang akan datang. Contohnya seperti penurunan intelektual, rentan terhadap penyakit tidak menular/degeneratif dan melahirkan bayi dengan risiko berat lahirnya lebih rendah (UNICEF, 2017).

Umumnya di wilayah provinsi-provinsi di Indonesia, jumlah prevalensi stunting mengalami penurunan selama kurun tiga tahun terakhir. Jika diidentifikasi berdasar persentase balita pendek, prevalensi tertinggi pada tahun 2015 adalah di Provinsi Sulawesi Barat sebesar 19\%, kemudian terjadi perubahan nilai presentase pada tahun 2016, yakni sebesar 20,05\% di Provinsi Kalimantan Barat, lalu pada Tahun 2017 prevalensi stunting tertinggi berpindah posisi ke Provinsi Kalimantan Tengah dengan nilai sebesar 17,89\% (Nelayesiana, 2019).

Faktor keluarga dan lingkungan mempengaruhi kejadian stunting pada anak, karena gizi seorang anak sangat tergantung pada ibu dan keluarganya (Sutarto et al., 2018). Penelitian Agustia et al. (2018) melaporkan pemberian ASI yang tidak eksklusif, riwayat penyakit infeksi, dan imunisasi yang tidak lengkap merupakan faktor risiko terjadinya stunting pada balita usia 12-59 bulan di wilayah tambang emas Poboya Palu. Hasil penelitian Resti et al. (2018) menunjukkan bahwa riwayat penyakit infeksi merupakan faktor risiko stunting dengan nilai OR yaitu 3,400 yang menunjukkan bahwa balita memiliki 3,400 kali lebih besar berisiko stunting dibandingkan dengan balita yang tidak menderita 
penyakit infeksi. Hasil yang sama juga dilaporkan oleh Picauly \& Toy (2013) yang menyatakan bahwa balita yang menderita infeksi 10,298 kali lebih berisiko untuk menderita stunting. Infeksi menjadi salah satu penyebab terjadinya masalah gizi salah satunya stunting. Infeksi dan malnutrisi seringkali terjadi secara bersamaan. dan infeksi yang menyebabkan malnutrisi ini dapat terjadi karena seseorang saat sakit membutuhkan gizi yang lebih untuk melawan penyakitnya (Darmadi (2008).

Penelitian yang dilakukan pada anak usia 7-13 tahun yang tinggal di sekitar area tambang emas tradisional di Poboya Palu, bahwa asupan zat gizi yang kurang berupa asam amino, asam folat dan zat besi pada anak yang berkorelasi positif dengan kadar hemoglobin dan korelasi yang tidak signifikan terhadap kejadian stunting (Bohari et al, 2017).

Selain malnutrisi dan penyakit infeksi, masyarakat yang tinggal di area PESK juga berisiko terhadap diare (Veiga et al., 2006). Penelitian Stewart et al. (2013) di Uganda menjelaskan bahwa anak yang menderita diare memiliki nafsu makan yang menurun sehingga asupan gizi yang didapat cenderung menurun. Serta tingginya kejadian diare disertai gangguan penyerapan dan tingkat kehilangan zat gizi secara berulang-ulang pada anak menyebabkan terganggunya proses pertumbuhan. Balita stunting dengan prevalensi diare yang tinggi akan memiliki tingkat daya imun yang lebih rendah.

Penelitian cross sectional yang dilakukan oleh Wyatt et al (2019), melaporkan bahwa menurunnya respons imun atau system kekebalan tubuh pada anak yang tinggal di daerah dengan risiko paparan merkuri yang tinggi dan diperburuk oleh malnutrisi yang terjadi secara bersamaan.

Menurut Vilcins et al. (2018) faktor risiko berasal dari lingkungan yang berhubungan dengan terjadinya stunting diantaranya adalah sumber air, kebersihan lingkungan tempat tinggal, polusi udara, infeksi parasit, paparan logam diantaranya adalah merkuri. Penelitian yang dilakukan oleh Marques et al. (2012) terhadap anak-anak yang tinggal di sekitar tambang timah di Bom Futuro, Brazil menunjukkan hasil korelasi positif meskipun tidak signifikan antara kandungan metil merkuri yang ada di rambut dengan kejadian stunting. Penelitian lain pada 252 bayi sehat di Korea berusia 6-24 bulan dari klinik rawat jalan periode tahun 2009/2010 dan 2013/2014, menunjukkan adanya hubungan negatif yang signifikan antara kadar merkuri dalam rambut dengan antropometri pada bayi periode 2013/2014, namun tidak signifikan pada bayi periode 2009/2010 (Chang et al., 2015).

Artikel ini disusun dengan harapan dapat memberikan gambaran tentang risiko stunting akibat paparan merkuri bagi anak-anak yang tinggal di sekitar area PESK. Namun masih terbatasnya penelitian terkait dan temuan yang ada masih belum jelas, sehingga penelitian lebih mendalam perlu dilakukan.

\section{KESIMPULAN}

Berdasarkan dari hasil penelusuran dari berbagai penelitian atau buku elektronik menyebutkan bahwa anak-anak yang tinggal di area PESK sangat rentan terhadap paparan merkuri baik secara inhalasi dengan menghirup uap merkuri atau melalui ingesti dengan mengkonsumsi makanan atau minuman yang mengandung merkuri. Berbagai faktor risiko yang mengancam anak-anak yang tinggal di area PESK dapat mengakibatkan stunting, meskipun masih sedikit penelitian dan menunjukkan hasil yang tidak signifikan penelitian dan menunjukkan hasil yang tidak signifikan terkait kan paparan merkuri dengan stunting.

\section{UCAPAN TERIMA KASIH}

Ucapan terimakasih kami tujukan kepada Kementerian Pendidikan dan Kebudayaan Republik Indonesia (Kemendikbud RI) yang telah mendanai kegiatan penelitian ini melalui Program Kreativitas Mahasiswa pada skema Penelitian (PKM-P) tahun 2020. Terimakasih kami ucapkan kepada Dosen Pembimbing serta Kepala Bidang Kemahasiswaan Universitas Muhammadiyah Palangkaraya yang telah membimbing kami dalam penyusunan naratif review ini.

\section{DAFTAR PUSTAKA}

Bohari., Rahman, N., Indriany. 2017. "Asupan Zat Gizi, Stunting dan Anemia Pada Anak Sekolah Dasar di Daerah Tambang Tradisional Poboya, Palu". Universitas Tadulako: Fakultas Kesehatan Masyarakat.

Bose-O'Reilly, S., Lettmeier, B., Matteucci Gothe, R., Beinhoff, C., Siebert, U., Drasch, G., 2008. 
Mercury as a serious health hazard for children in gold mining areas. Environ. Res. 107, 89-97.

Chang, J.Y., Park, J.S., Shin, S., Yang, H.R., Moon, J.S., Ko, J.S., 2015. Mercury exposure in healthy Korean weaning-age infants: Association with growth, feeding and fish intake. Int. J. Environ. Res. Public Health 12, 14669-14689.

Darmadi, 2008. Infeksi Nosokomial, Jakarta: Salemba Medika.

De Onis, M., Blössner, M., Borghi, E., 2012. Prevalence and trends of stunting among preschool children, 1990-2020. Public Health Nutr. 15, 142-148.

de Onis, M., Branca, F., 2016. Childhood stunting: A global perspective. Matern. Child Nutr. 12, 1226.

Ekorinawati. 2010. Hubungan Asupan Zat Besi Dengan Kadar Hemoglobin dan Kadar Ferritin Pada Anak Usia 6 sampai 24 Bulan Di Puskesmas Kratonan Surakarta. [Surakarta]: Universitas Muhammadiyah Surakarta

Esdaile, L.J., Chalker, J.M., 2018. The Mercury Problem in Artisanal and Small-Scale Gold Mining. Chem. - A Eur. J. 24, 6905-6916.

Feingold, B.J., Berky, A., Hsu-Kim, H., Rojas Jurado, E., Pan, W.K., 2020. Population-based dietary exposure to mercury through fish consumption in the Southern Peruvian Amazon. Environ. Res. 183, 108720.

Gibb, H., O’Leary, K.G., 2014. Mercury exposure and health impacts among individuals in the artisanal and small-scale gold mining community: A comprehensive review. Environ. Health Perspect. 122, 667-672.

Nelayesiana, B., 2019. Benarkah Pemberian Asi Dapat Menekan Ancaman Stunting?. Pekanbaru: Badan Pusat Statistik Pekanbaru.

Kemenkes RI, 2018. Buletin Stunting. Kementeri. Kesehat. Republik Indones. 301, 1163-1178.

Laksono, A.D., Kusrini, I., 2019. Gambaran Prevalensi Balita Stunting dan Faktor yang Berkaitan di Indonesia: Analisis Lanjut Profil Kesehatan Indonesia Tahun 2017 Gambaran Prevalensi Balita Stunting dan Faktor yang Berkaitan di Indonesia: Analisis Lanjut Profil Kesehatan Indonesia Tahu. Researchgate 0-12.

Marques, Rejane C., Dórea, J.G., Leão, R.S., Dos
Santos, V.G., Bueno, L., Marques, Rayson C., Brandão, K.G., Palermo, E.F.A., Guimarães, J.R.D., 2012. Role of methylmercury exposure (from Fish Consumption) on growth and neurodevelopment of children under 5 years of age living in a transitioning (tin-mining) area of the Western Amazon, Brazil. Arch. Environ. Contam. Toxicol. 62, 341-350.

Ohlander, J., Huber, S.M., Schomaker, M., Heumann, C., Schierl, R., Michalke, B., Jenni, O.G., Caflisch, J., Muñoz, D.M., Von Ehrenstein, O.S., Radon, K., 2013. Risk factors for mercury exposure of children in a rural mining town in northern Chile. PLoS One 8.

Park, J.D., Zheng, W., 2012. Human exposure and health effects of inorganic and elemental mercury. J. Prev. Med. Public Heal. 45, 344352.

Picauly, I. \& Toy, S.M., 2013. Analisis Determinan Dan Pengaruh Stunting Terhadap Prestasi Belajar Anak Sekolah di Kupang dan Sumba Timur, NTT. Jurnal Gizi dan Pangan, 8(72), hal. 55-62.

Reinhardt, K., Fanzo, J., 2014. Addressing Chronic Malnutrition through Multi-Sectoral, Sustainable Approaches: A Review of the Causes and Consequences. Front. Nutr. 1.

Resti, A., Nurdin, R., \& Hermiyanty. 2018. "Faktor Risiko Kejadian Stunting Pada Balita Usia 1259 Bulan di Wilayah Tambang Paboya, Kota Palu". Univeritas Tadulako: Fakultas Kesehatan Masyarakat.

Riaz, A., Khan, S., Muhammad, S., Liu, C., Shah, M.T., Tariq, M., 2018. Mercury contamination in selected foodstuffs and potential health risk assessment along the artisanal gold mining, Gilgit-Baltistan, Pakistan. Environ. Geochem. Health 40, 625-635.

Schipper, I., Haan, E. De, Dorp, M. Van, 2015. Gold from children's hands Use of child-mined gold by the electronics sector.

Stewart, C.P. et al., 2013. Contextualising complementary feeding in a broader framework for stunting prevention. Maternal and Child Nutrition, 9(2), hal. 27-45.

UNICEF, 2017. Laporan Baseline SDG tentang Anak-Anak di Indonesia. Kementeri. Perenc. Pembang. Nas. dan United Nations Child. Fund 


\section{$1-105$.}

Veiga, M., Metcalf, S., Baker, R., Klein, B., Davis, G., Bamber, A., Siegel, S., Singo, P., 2006. Manual for Training Artisanal and Small-scale Gold Miners. Man. Train. Artis. Small-scale Gold Miners 144.

Vilcins, D., Sly, P.D., Jagals, P., 2018. Environmental risk factors associated with child stunting: A systematic review of the literature. Ann. Glob. Heal. 84, 551-562.

Weinhouse, C., Ortiz, E.J., Berky, A.J., Bullins, P., Hare-Grogg, J., Rogers, L., Morales, A.M., Hsu-Kim, H., Pan, W.K., 2017. Hair mercury level is associated with anemia and micronutrient status in children living near artisanal and small-scale gold mining in the Peruvian Amazon. Am. J. Trop. Med. Hyg. 97, 1886-1897.

WHO (World Health Organization), 2007. Exposure to mercury: A major public health concern. Geneva: WHO.

WHO, 2016. Environmental and Occupational Health Hazards Associated with Artisanal and SmallScale Gold Mining; 9241510277;World Health Organization: Geneva, Switzerland.

Wyatt, L., Ortiz, E.J., Feingold, B., Berky, A., Diringer, S., Morales, A.M., Jurado, E.R., HsuKim, H., Pan, W., 2017. Spatial, temporal, and dietary variables associated with elevated mercury exposure in peruvian riverine communities upstream and downstream of artisanal and small-scale gold mining. Int. J. Environ. Res. Public Health 14.

Wyatt, L., Permar, S.R., Ortiz, E., Berky, A., Woods, C.W., Amouou, G.F., Itell, H., Hsu-Kim, H., Pan, W., 2019. Mercury exposure and poor nutritional status reduce response to six expanded program on immunization vaccines in children: An observational cohort study of communities affected by gold mining in the peruvian amazon. Int. J. Environ. Res. Public Health 16, 1-22.

Zhang, L.X., Koroma, F., Fofana, M.L., Barry, A.O., Diallo, S., Songbono, J.L., Stokes-Walters, R., Klemm, R.D., Nordhagen, S., Winch, P.J., 2020. Food security in artisanal mining communities: An exploration of rural markets in northern Guinea. Foods 9, 1-14. 